\title{
CONSIDERACIONES TÉCNICAS SOBRE EL USO DE BIORREACTORES DE INMERSIÓN TEMPORAL (BIT) *
}

\section{TECHNICAL CONSIDERATIONS ON THE USE OF TEMPORARY IMMERSION BIOREACTORS}

Jara, G.', Muñoz. M.', Seemann. P'. y Daquinta, $\mathbf{M}^{2}$. 'Instituto de Producción y Sanidad Vegetal, Universidad Austral de Chile. Chile. E-mail: gjara@ uach.cl.

${ }^{2}$ Centro de Bioplantas. Universidad de Ciego de Avila (UNICA), Ciego de Avila, Cuba.

\section{INTRODUCCIÓN}

El uso del medio líquido para la propagación in vitro se considera una técnica ideal para la propagación masiva de plantas, porque reduce la manipulación y es un requisito indispensable para la automatización del proceso, además de disminuir los costos operacionales. Sin embargo, su principal desventaja es la hiperhidricidad de los tejidos. Para evitar este problema, se desarrollaron diferentes procedimientos, como el cultivo en agitación, el empleo de puentes de papel de filtro, tapones de celulosa, esponjas, canastas flotantes etc. así como el empleo de agentes químicos antivitrificantes. Alvard et al. (1993) estudiaron cinco métodos diferentes de cultivo en comparación con el medio sólido en la propagación de meristemas de bananos, desde la cual surgió un nuevo concepto para el cultivo in vitro en medio líquido: la inmersión temporal. Esta técnica se ha empleado exitosamente en la proliferación de brotes múltiples, ya sea mediante organogénesis o embriogénesis somática (Cuadro 1) o para la obtención de brotes aptos para el enraizamiento ex vitro y la aclimatización siendo Cuba, uno de los países pioneros en el desarrollo tecnológico de este sistema (Escalona, et al. 1999). Mediante un entrenamiento realizado en el Centro de Bioplantas (Cuba), se logró obtener los conocimientos y capacitación para implementar y desarrollar el Sistema de Inmersión Temporal en el Laboratorio de Cultivo de Tejidos Vegetales, de la Universidad Austral de Chile, el cual fue aplicado inicialmente para

Cuadro 1. Coeficientes de multiplicación en micropropagación convencional (MC) y en Biorreactores de Inmersión Temporal (BIT).

Table 1. Multiplication coefficients on Conventional Micropropagation (CM) and Temporary Immersion Bioreactors (TIB).

\begin{tabular}{|c|c|c|c|}
\hline Cultivo & Variedad & $\mathrm{MC}$ & $\mathrm{BIT}$ \\
\hline \multirow[t]{8}{*}{ Caña de Azúcar } & Cayena Lisa & 8.0 & 688 \\
\hline & C 91-301 & 3.7 & 34.1 \\
\hline & C1051-73 & 4.1 & 580 \\
\hline & C120-78 & 3.9 & 30.2 \\
\hline & C $323-68$ & 4.3 & 39.5 \\
\hline & C85-212 & 38 & 31.6 \\
\hline & c85-214 & 4.0 & 29.8 \\
\hline & CP-5243 & 4.0 & 32.5 \\
\hline \multirow[t]{2}{*}{ Malanga } & INIVIT & 3.0 & 10.44 \\
\hline & México 1 & 2.8 & 7.71 \\
\hline \multirow[t]{3}{*}{ Banano } & FHIA-18 & 3.8 & 7.40 \\
\hline & FHIA-01 & 3.4 & 10.4 \\
\hline & Gran Enano & 4.0 & 16.6 \\
\hline \multirow[t]{2}{*}{ Syngonium } & W. Butterfly & 7.3 & 28.0 \\
\hline & Pixie & 2.2 & 18.4 \\
\hline Spathyphyllum & Sensation & 3.7 & 17.6 \\
\hline Phylodendrom & Xanadu & 2.0 & 8.8 \\
\hline
\end{tabular}



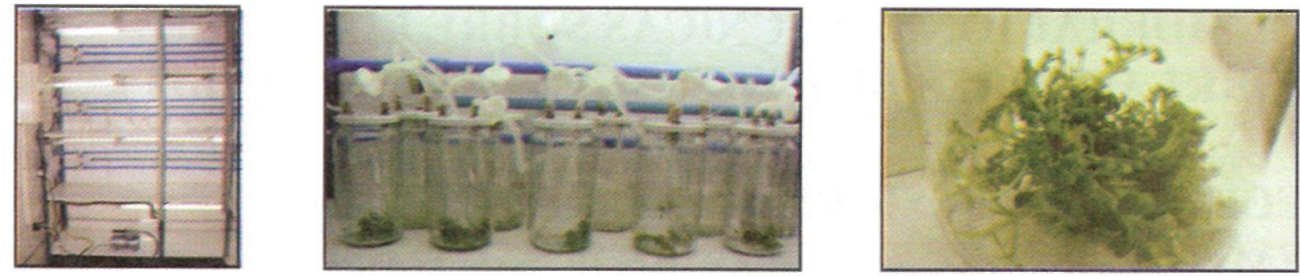

Figura 1. Montaje Sistema de Inmersión Temporal en Laboratorio de Cultivo de Tejidos Vegetales de la Universidad Austral de Chile.

Figure 1. Ensamble Temporary Immersion System in the Vegetable Tissue Culture Laboratory of the Universidad Austral de Chile.

el cultivo de tres especies, de tal forma de controlar alguno de los factores que influyen en el manejo de los BIT y del material vegetal, y de esta manera dejarlo en condiciones aptas para ser utilizado en la micropropagación de diferentes especies de Rhodophiala chilenas.

\section{MATERIAL Y MÉTODOS}

Para la instalación del sistema se utilizó la tecnología propuesta por Escalona (et al. 1999). Las baterías de cultivo fueron frascos de vidrio de $1000 \mathrm{ml}$ con tapa Twist off, con nipples de bronce, anillos de goma del nipple, mangueras de silicona autoclavables de 17", tuberías de $\mathrm{PVC}$, filtros hidrófobos de $50 \mathrm{~mm}$ de diámetro y $0,2 \mathrm{~mm}$ de tamaño de poro, electroválvulas simples, programadores digitales y un compresor de aire. En un frasco se colocaron los explantes compuestos de diez brotes de Lobelia bridgesii, Ruta graveolens, y Nothofagus alessandri. Se sembraron tres frascos de cada especie utilizando $40 \mathrm{ml}$ de medio de cultivo por explante compuesto por las sales y vitaminas de Murashigue y Skoog (1962) adicionado con 2,0\% de sacarosa, $0,1 \mathrm{mg} \mathrm{L}^{-1}$ de ANA y $1,0 \mathrm{mg} \mathrm{L}^{-1} \mathrm{BAP}$, con un tiempo de inmersión de 3 minutos dos veces al día, por 25 días.

\section{RESULTADOS Y DISCUSIÓN}

El trabajo operacional de los BIT, desde la esterilización del medio de cultivo hasta la siembra de las baterías involucra una menor manipulación de los frascos de cultivo, con lo cual los riesgos de contaminación son menores. Sin em- bargo, para que esto sea efectivo, es necesario tomar ciertas precauciones, como ser; evitar que los filtros tomen contacto con el vapor del autoclave, que los nipples, tapas y mangueras estén correctamente apretados, de tal forma de evitar que se suelten producto del calor y la presión, además de evitar salidas de aire durante su funcionamiento. A pesar de que en la instalación de los BIT no fueron consideradas algunos de estos aspectos no se presentaron pérdidas de material vegetal por contaminación, con lo cual se logró un $100 \%$ de establecimiento de los brotes en las diferentes especies. Cada batería funcionó correctamente, lográndose la regeneración de brotes nuevos a partir de la primera semana, no obstante, uno de los factores importantes ha considerar es el tamaño de los explantes. De esta manera se puede concluir que la puesta en marcha de este sistema de multiplicación fue eficiente, con lo cual se encuentra en condiciones apropiadas para ser utilizado en ensayos de micropropagación de Rhodophiala sp.

\section{REFERENCIAS}

ALVARO. D.; COTE, F.; TEISSON, C 1993. Comparison of methods of liquid medium culture for banana micropropagation. Effect of temporary immersion of explants. Plant Cell Tissue and Organ Culture. 32: 55-60

ESCALONA M, J.C. LORENZO, J.C.; GONZÁLEZ, B.; DAQUINTA, M.; GONZÁLEZ, J.L.; DESJARDINS, Y.; BORROTO, G. 1999. Pineapple (Ananas comosus L. Merr) micropropagation in temporary immersion systems. Plant Cell Reports 18: 743-748. 